\title{
Human leukocyte antigen class I supertypes and viral control in HIV-1 infected former plasma donors from China
}

\author{
J Hao ${ }^{*}$, K Hong, J Chen, M Jia, Y Ruan, Y Shao \\ From AIDS Vaccine 2012 \\ Boston, MA, USA. 9-12 September 2012
}

\section{Background}

The role of human leukocyte antigen (HLA) class I supertypes in controlling human immunodeficiency virus type 1 (HIV-1) infection in Chinese has not been established. The aim of this study is to examine the frequency of HLA-A and HLA-B alleles and supertypes of 222 HIV-1 infected former plasma donors in central China and to investigate their impact on HIV-1 viral control.

\section{Methods}

HLA-A and HLA-B alleles were genotyped with PCR-SSP and sequence-based typing assay to four-digit resolution. The HLA alleles were classified functionally to 4 HLA-A supertypes and 6 HLA-B supertypes according to their shared peptide binding properties. Plasma viral load was determined using the Roche Amplicor ultrasensitive assay which has a lower detection limit of 50 copies HIV-1 RNA per ml.

\section{Results}

HLA-A03 supertypes(A03s) and HLA-B62 supertypes (B62s) were associated with lower viral load $(\mathrm{P}=0.0206$, $\mathrm{P}=0.0483$ ), whereas HLA- A24 supertypes(A24s) appeared to have an association with higher viral load $(\mathrm{P}=0.0483)$. There was a highly significant correlation between the genotypic supertypes(GS) and viral load (Kendall's tau b = $0.180, \mathrm{P}=0.000)$. The median viral load was lower among $A * 3001(\mathrm{P}=0.0139), \mathrm{A}^{*} 1101(\mathrm{P}=0.0096), \mathrm{B} * 5101(\mathrm{P}=0.0025)$, $B * 3501(P=0.0091)$ or $B * 4601(P=0.001)$ carriers and higher in $\mathrm{A}^{*} 2301(\mathrm{P}=0.0106)$ carriers.

National Center for AIDS/STD Control and Prevention, Beijing, China

\section{Conclusion}

HLA-A03s and -B62s may be associated with favorable HIV-1 viral control, A24s associated with unfavorable viral control; HLA-B*4601 within B62s and HLAA*2301 within A24s might contribute to the outcomes of HIV-1 viral control.

Published: 13 September 2012

doi:10.1186/1742-4690-9-S2-P167

Cite this article as: Hao et al:: Human leukocyte antigen class I

supertypes and viral control in HIV-1 infected former plasma donors from China. Retrovirology 2012 9(Suppl 2):P167.

Submit your next manuscript to BioMed Central and take full advantage of:

- Convenient online submission

- Thorough peer review

- No space constraints or color figure charges

- Immediate publication on acceptance

- Inclusion in PubMed, CAS, Scopus and Google Scholar

- Research which is freely available for redistribution 